\title{
If You Try, You'll Get By: Chinese Private Firms' Efficiency Gains from Overcoming Financial Constraints
}

\author{
Galina Hale \\ Federal Reserve Bank of San Franciscoa \\ Cheryl Long \\ Colgate University
}

January 2011

Working Paper 2010-21

http://www.frbsf.org/publications/economics/papers/2010/wp10-21bk.pdf

The views in this paper are solely the responsibility of the authors and should not be interpreted as reflecting the views of the Federal Reserve Bank of San Francisco or the Board of Governors of the Federal Reserve System. This paper was produced under the auspices for the Center for Pacific Basin Studies within the Economic Research Department of the Federal Reserve Bank of San Francisco. 


\title{
If You Try, You'll Get By:
}

\section{Chinese Private Firms’ Efficiency Gains from Overcoming Financial Constraints}

\author{
Galina Hale \\ Federal Reserve Bank of San Francisco ${ }^{\mathrm{a}}$ \\ Cheryl Long \\ Colgate University
}

\section{Introduction}

The importance of finances in economic development has long been advocated and empirically tested in the economic literature. As early as 1911, Schumpeter has linked the importance of financial services to firms' capacity in engaging technological innovation and thus a country's ability in economic development. Based on country-level analyses, King and Levine (1993) provide evidence that multiple indicators of financial development are not only positively correlated with the present levels of multiple economic indicators but also their future values. Using industry level data for a large number of countries, Rajan and Zingales (1998) show that industries with higher external finance requirements tend to grow faster in countries with more developed capital markets.

Thus, one big puzzle in China's rapid economic growth in the past three decades relates to the financial sector. On the one hand, the Chinese economy has experienced one of the fastest growth rates in the world continuously since the late 1970s, and the growth has been largely driven by the rapid development of the private sector, which substantially outpaced the growth rate of the state sector. On the other hand, the vast majority of researchers believe that the formal financial sector in China performs poorly by many standards, especially in their failure to provide finances to the 
private sector. How did the private sector in China manage to grow so rapidly with limited access to external finance? There are two avenues one could explore: alternative financing to overcome limited supply of external funds from the formal financial sector, and new ways in which firms may reduce their demand for external funds.

Previous studies addressing the puzzle focused mainly on alternative financing sources that include internal funds, informal loans (from family, friends, and acquaintances), foreign direct investment (FDI), and trade credit among private firms themselves and from other types of firms. While there is evidence that the first three alternative sources (internal funds, informal loans, and FDI) have been important in alleviating private firms' financial constraints (Allen, Qian, and Qian, 2005, 2007; Hèricourt and Poncet , 2008; Lardy 1998, 2004; Poncet, Steingress, and Vandenbussche, 2008), trade credit from other sectors (such as state-owned or foreign-invested sector) has been shown to play an insignificant role (Cull, Xu, and Zhu, 2009) or to be non-existent since the late 1990s (Hale and Long, 2010). ${ }^{\text {b }}$

In this paper we focus on the second avenue by investigating the ways in which Chinese private firms lower their demand for external financing and studying whether these methods lead to increased or decreased efficiency and productivity. To the best of our knowledge, only one other paper explores the finances of Chinese private firms from the demand side of finances: Long and Zhang (2010) point out that organizational innovations such as clustering may lead to a lower level of financial needs for Chinese firms by reducing fixed capital requirement and facilitating inter-firm credit. Here, we go further along this path by investigating two other channels, namely, the management of inventory and that of accounts receivable, which allow firms to reduce the demand for operating costs. 
Various studies provide evidence that private firms have been discriminated against in the financial market. Brandt and Li (2003) provide direct evidence that between 1994 and 1997 private firms were discriminated against by township branches of the Agricultural Bank of China and the local Rural Credit Cooperatives, compared to township enterprises. Dollar and Wei (2007) show that on average Chinese domestic private firms have significantly higher returns to capital than SOEs, implying more funds going to the SOEs, an inefficient allocation of financial resources. Liu and Siu (2006) similarly show that the "implied" cost of capital derived from their estimated structural parameters is substantially higher for private firms and foreign invested firms than for SOEs in China. More generally, Hsieh and Klenow (2009) estimate that Chinese manufacturing sector could potentially improve its total factor productivity by $30-50 \%$ through more efficient capital allocation.

Using balance-sheet data from Chinese Industrial Surveys of Medium-sized and Large Firms for 2000-2006 (the NBS survey) and survey data from the Large-Scale Survey of Private Enterprises in China that was conducted in five waves between 1997 and 2006, we first confirm that, consistent with conventional wisdom, private firms still had more limited access to external finance during the period of rapid economic growth prior to the global recession. Moreover, we find substantial variations among private firms: While the small private firms face more financial constraints, the more established large private firms seem to have access to finances more equal to their stateowned counterparts.

We then turn to the main analysis of our paper - channels through which private firms reduce their demand for operating funds. Using the NBS survey data as well as the Survey of Private Enterprises data, we study the relationship between firms' access to external finances and the ratios of inventories and accounts receivable to sales. As inventories make up a large part of daily working capital, a lower level of inventory implies fewer funds required for working capital, and 
thus less need for finances. Likewise, lower average level of accounts receivable means that firms recover their revenues and use them for working capital financing more quickly, thus relying less on external financing.

First of all, we find that the ratios of inventory to sales and accounts receivable to sales are substantially lower in private firms than in firms of other ownership types, even after controlling for various firm characteristics, industry, and location. Next, we show that these ratios depend on our measures of access to external finance both in a cross-section and in the fixed-effects panel. This suggests that not only firms with less access to credit have lower ratios of inventories and accounts receivable to sales (cross-section results), but also that firms make greater adjustments in their inventories and accounts receivable when credit gets tighter (fixed-effects panel results). These results are robust to adjusting measures of inventory and accounts receivable to sector averages and using lagged values of our measures of access to financing. Moreover, we find that for firms in sectors that are more dependent on external financing the relationships between access to finance and inventory and accounts receivable ratios are stronger.

An important question is whether the low levels of inventories and accounts receivable induced by limited access to external finances are in fact below the levels necessary to guarantee optimal sales. In other words, are the low ratios of inventories and accounts receivable observed in Chinese private firms just another indicator of detrimental effects of limited access to external finances? One warning sign is the fact that these ratios for private firms are even lower than for those in majority foreign-invested firms, which are thought to be the most efficient among Chinese firms. To address this question, we estimate non-linear regressions of various measures of firm profitability on inventory and accounts receivable ratios, and find that firm profitability is monotonically 
decreasing in these ratios. In other words, there is no evidence that low ratios of inventories and accounts receivable to sales in private firms are associated with lower profitability.

We take a step further and find that lower levels of inventory and accounts receivable are actually associated with higher levels of productivity, and more so in industries with higher shares of final goods inventory in total inventory and in sectors that use more trade credit. The results for inventory are consistent with the findings made by Lieberman and Demeester (1999) for Japanese car manufacturers. Here the argument is that a lower inventory level makes it easier to expose and subsequently resolve problems throughout the production process, leading to higher productivity. On the other hand, the higher productivity in firms with lower accounts receivable/sales ratios may be explained by the firm's greater ability to fully utilize its production capacity (Fisman 2001), to better coordinate activities among various employees, and to finance processes, products, or technology development that help enhance productivity. Thus, lower levels of inventory and accounts receivable increase firms’ profitability through both higher productivity and lower financial costs.

It is important to emphasize that our results do not imply that there are no costs associated with limited access to financing by private firms. It is quite likely that restricted access to credit is impeding the development of Chinese private firms by limiting fixed assets investment and growth. We do, however, show that private firms in China have found ways of coping with day-to-day shortage of finances through becoming more cost effective in ways that do not harm their profitability. Such efficiency improvements also make private firms in China more competitive compared to their state-owned counterparts in China and potentially more competitive compared to less constrained firms in other countries. In fact, another way to see our findings is that SOEs have 
extraordinarily easy access to credit which leads them to accumulate inefficiently high levels of inventory and accounts receivable.

The rest of the paper is organized as follows. Part 2 uses new data to demonstrate that private firms are more financially constrained compared to state-owned firms. Part 3 shows that firms respond to constrained financial access by reducing their levels of inventories and accounts receivable. Part 4 analyzes the effects of such mechanisms on profitability and productivity, and Part 5 concludes.

\section{Do state-owned firms have easier access to external financing?}

Our data come from two main sources. First, we use balance sheet and ownership information from the Chinese Industrial Surveys of Medium-sized and Large Firms for 2000-2006, which includes all state-owned firms and firms of other ownership types that are in excess of a certain scale. This data set is commonly referred to as the National Bureau of Statistics (NBS) manufacturing census, and consists of an unbalanced panel with a total of 496,738 firms for 2000-2006. ${ }^{\mathrm{c}}$ For short, we will refer to this data set as the "census" data. We use two versions of these data - the cross-section of firms in the last year of our sample (297,665 firms) and a balanced panel that only includes firms

that were in our data in each of the years during 2000-2006 (48,382 firms, 338,674 observations). ${ }^{\mathrm{d}}$

Second, we use survey data from the Large-Scale Survey of Private Enterprises in China jointly conducted by the All China Federation of Industrial and Commerce (ACFIC) and the United Front of the Chinese Communist Party in 1997, 2000, 2002, 2004, and 2006, often with help from the Bureau of Industry and Commerce. This survey is a repeated cross-section in which firms are not 
matched across years. A total of 18,527 firms are surveyed over all the years, and only private firms are included. For short, we will refer to this data set as the "survey" data.

The census data covers firms of all ownership types, including those with foreign capital share. We classify firms by ownership types in two ways - by the registration type, and by the type of investor holding the majority share of the paid-up capital. While the first measure may be outdated, as the registration of the firm may not change as soon as the firm's capital structure changes, it is possible that the registration type, rather than the de facto ownership structure determines the access to financing. We will refer to the two classifications as the de jure ownership type (by registration) and the de facto ownership type (by actual shares).

Using the 2006 cross-section, Table 1 shows that in most cases there is a good match between the two classifications. Note that one exception is the set of firms with the majority share held by “legal person,” which are mostly registered as private firms, but could also be in other categories. In what follows, we will analyze results using both classifications, but to spare the reader from all the details, we will only report results from the de facto classification analysis and point to the differences wherever they arise.

[Table 1 about here]

It is important to note that the samples of firms in the three data sets we consider - the 2006 crosssection of the census, the balanced panel from the census, and the private firm survey - are quite different. The manufacturing census has a minimum size threshold for including private firms, which was revised and simplified in 2004. Consequently, many of the smaller private firms that 
appear in the 2006 cross-section are not included in the balanced panel that extends back to 2000 . The firms covered in private firm surveys, on the other hand, are almost exclusively small firms. As a result, the balanced panel data includes mostly SOEs and large private firms, the 2006 census cross-section also includes smaller private firms, while the private firm survey includes only private firms, which are mostly small ones.

As discussed previously, a main indicator of how efficiently the financial system operates in China is whether banks treat firms of different ownership types differently when extending loans to them. Thus we first study how SOEs differ in their access to formal loans as compared to private firms. We confirm that state-owned firms still have easier access to external financing: they tend to have slightly higher leverage (debt/total assets) and higher share of financial expense in total expense, while they pay half as much expense per unit (RMB) of their external financing compared to private firms (see Table 2). ${ }^{\mathrm{e}}$

For the balanced panel of the firms, we see that while leverage was more or less unchanged during our sample period for SOEs, it in fact declined for private firms, holding the sample constant. Moreover, for older and larger private firms that were in our balanced panel since 2000, leverage is in fact a bit higher than for SOEs and is declining. If we include new firms, however, as in our 2006 cross-section, the average leverage of the private firms is substantially lower than in the balanced sample, suggesting that new entrants have more restricted access to financing than older private firms and than SOEs. In addition, smaller private firms, the ones included in our survey data, have less than half the leverage level of the private firms in the census, indicating that access to finance is particularly hard for young small private firms. 
Looking at the share of financial expense in total expense, we find that even in the balanced panel the share is a lot lower for private firms than for the SOEs. It becomes even lower once we include all firms as in our 2006 cross-section. At the same time, interest expense as a ratio to total debt is almost twice as high for private firms as it is for SOEs, in both the cross-section and the balanced panel. This indicates that when private firms do access external finance, they pay substantially more for it than SOEs. In addition, we see that total financial expenses and interest expenses have declined on average for SOEs during our sample period, while they remained basically unchanged for private firms.

[Table 2 about here]

As private firms in China are on average younger and smaller than state-owned firms and therefore lack credit history and reputation, one potential reason for the latter's easier access to finances could be their better creditworthiness rather than prejudice against private firms in the formal financial sector. We address this difficulty in interpretation by estimating the effects of ownership controlling for size and measures of creditworthiness (such as liquidity and profitability) using the regression analysis.

Table 3 reports the results of the regression analysis that conducts this test for the 2006 crosssection. We do see that at least for leverage size matters as well - once we control for the log of assets, the coefficient on the SOE dummy falls by about half, indicating that half of the difference in leverage between private firms and SOEs in the 2006 census cross-section is due to the fact that state firms tend to be larger. Nevertheless, we still find that state-owned firms have significantly higher leverage, larger ratio of financial to total expenses, and lower share of accounts payable in total debt, even after controlling for size, profitability, and liquidity measures. These findings 
confirm that state-owned firms have easier access to formal external finance and rely less on informal finance than other firms.

[Table 3 about here]

We repeat this analysis for the balanced panel to see what the trends were between 2000 and 2006 (or between 2003 and 2006 in the case of accounts payable over debt). To this end, we interact the indicator for majority state-owned firms with the time trend and estimate a panel regression by GLS with random effects (see Table 4). We find that although in our balanced panel sample the leverage is roughly the same for private firms and SOEs, the other two measures indicate that even for this sample, which only includes larger and older private firms, the private firms have more difficult access to credit. While these differences between state-owned and other firms diminish over our sample period, the rate of convergence is very slow for the share of financial and interest expenses. Moreover, if we consider the ratio of long term debt to long term assets, we find that state-owned firms had larger, and growing, ratio throughout the sample period. As a result, there is evidence for more limited financial access by Chinese private firms as late as 2006, shortly before the outbreak of the recent financial crisis.

[Table 4 about here]

\section{Reducing financing needs through inventory and accounts receivable}

Given the above findings, how is it possible that private firms in China have been growing so fast? We propose two ways private firms may have used to lower their demand for external financing, which, to the best of our knowledge, haven't been explored in the literature. Table 5 shows that in 
our 2006 census cross-section, private firms have substantially lower inventory/sales ratios than their SOE counterparts: $14 \%$ vs. $31 \%$. They also have lower accounts receivable/sales ratios than SOEs: $13 \%$ vs. $16 \%$. In fact, among firms of all ownership types, both of these ratios are the lowest for the subsample of private firms.

[Table 5 about here]

As these firms are all industrial firms exceeding a certain size, such huge differences in the inventory/sales ratio and the accounts receivable/sales ratio most likely indicate much more efficient management of inventories and accounts receivable, and thus lower need for working capital in private firms, as compared to SOEs. To test the hypothesis that the low levels of inventory and accounts receivable reflect the attempt of financially constrained firms to reduce their need for working capital funds, we regress the inventory and accounts receivable ratios on our measures of credit constraint, namely leverage, financial expense/total expense, and interest expense/debt ratios. The results are presented in Table 6, with panel A giving the 2006 crosssection results and panel B giving the firm fixed effects results for the balanced panel. As expected, we find statistically significant correlations for all three measures of access to external financing in both the cross-section (with ownership and industry dummies included) and in the panel (with firm and year fixed effects).

[Table 6 about here]

The cross-section results show that firms with easier access to external financing, reflected by higher leverage, higher ratio of financial to total expenses, or lower ratio of interest expenses to total debt, tend to have higher level of inventories and accounts receivable. Fixed-effect panel results further show that when access to external finance gets tighter for an individual firm, as 
reflected in this firm's lower leverage, lower ratio of financial to total expenses, or higher ratio of interest expenses to total debt, it lowers its inventory and accounts payable ratios.

To address a potential concern that these results are driven by the changes in the denominator of both inventory and accounts payable ratios, namely sales, over time, we add to our panel estimation the growth rate of sales as a control variable. The results are reported in column (5) of Table 6B, with all the main results preserved. In particular, coefficients on the variables of interest remain largely unchanged even though we now have one less year of data for each firm.

In terms of economic importance of the effects, we find in the cross-section sample that firms with access to finance the same as an average private firm (55\% leverage, $1.6 \%$ ratio of financial to total expenses, and 3\% ratio of interest expenses to total debt) will have inventory to sales ratio that is 4.3 percentage points lower and accounts receivable to sales ratio that is 1.6 percentage points lower than a firm with access to finance equal to an average state owned firm (56\% leverage, $4.7 \%$ ratio of financial to total expenses, and $1.6 \%$ ratio of interest expenses to total debt). These differences explain a large fraction, $28 \%$ and $61 \%$ of the differences in the inventory to sales and accounts receivable to sales ratios, respectively, between an average private firm and an average SOE.

In the panel we find that if access to external finances improves from the average level of private firms (leverage of $60 \%$, financial to total expense of $2.7 \%$, and interest expense to total debt of $3 \%$ ) to the average level of state owned firms ( $56 \%, 5.7 \%$, and $1.9 \%$, respectively), the inventory to sales ratio would increase by 3.6 percentage points, which would explain just over a quarter of the difference in the ratio between private and state owned firms. The same change would lead to an increase in the accounts receivable to sales ratio by 1 percentage point, explaining a third of the difference between private and state-owned firms. These magnitudes are large, given that they are 
identified by within variation over time in the relevant variables for individual firms, and that private firms in the balanced panel sample are older and larger and thus tend to be more similar to state owned companies.

We also study the patterns using the private firm survey data, which provides information on small private firms. Unfortunately, this survey does not provide information on inventory, but we can still analyze the effects of financing constraints on accounts receivable to sales ratio. Moreover, as financial costs are not available in the survey data, we only use leverage and interest rate as measures of credit constraints. Finally, the repeated cross-section nature of the data precludes us from conducting firm fixed effects estimation, but we do control for industry, province, and year fixed effects in the analysis.

As Panel C in Table 6 shows, leverage has positive and significant effects on the accounts receivable to sales ratio. Thus, the results obtained are largely in line with those for the census data, suggesting that the positive correlation between access to external finances and the level of working capital applies to small Chinese firms as well as large and medium-sized firms. Furthermore, the estimated effect of leverage on accounts receivable is larger than what we obtained for the large and medium-sized firms, suggesting greater sensitivity of small private firms' accounts receivable ratio to the availability of external funds. ${ }^{\mathrm{f}}$

A natural concern with the results described above is the potential endogeneity. There may be some other factors---unobserved to researchers---that cause firms to face more financial constraints and at the same time carry lower levels of inventory and accounts receivable. To address this issue, we conduct a few robustness tests using our balanced panel data. First, we compute the inventory/sales ratio and accounts receivable/sales ratio relative to the sector averages and rerun the estimations. 
This adjustment allows us to make sure that our results are not driven by differences in inventory and sales technologies across industries. Panel A of Table 7 presents the results from this analysis. We can see that not only our results remain qualitatively the same, but the magnitudes of the coefficients are essentially unchanged.

[Table 7 about here]

Next we repeat the analysis with all three measures of access to external finances lagged by one year. Since our estimation is conducted with firm fixed effects, the coefficients are identified by over-time variations in our dependent and independent variables. Lagging independent variable by one year allows us to test whether our main results are driven by reverse causality. Panel B in Table 7 shows the results of this test. With the exception of lagged leverage in the accounts receivable regressions, our results remain qualitatively unchanged, although coefficients are somewhat smaller in magnitude. This suggests that we cannot reject causal relationship between limited access to external finance and lower levels of inventories and accounts receivable.

We then adopt the Rajan-Zingales approach to study how the relationship between financial constraints and inventory or accounts receivable levels differ across sectors with different degrees of reliance on external finances. If our argument is correct that the lower level of inventory or accounts receivable is a result of financial constrains faced by firms, then such an effect should be larger in sectors that have a greater reliance on external finances. To test this possibility, we include in the above estimation additional explanatory variables: the index of external finance reliance (based on U.S. data from 1980 from Rajan and Zingales 1998) and its interactions with the various financial constraint measures. ${ }^{\mathrm{g}}$ The results presented in Panel C of Table 7 show that firms in sectors more dependent on external finances reduce their inventory and accounts payable levels 
more in response to an increase in financial constraints. These findings are consistent with our hypothesis that financially constrained firms reduce their financial needs by adjusting their inventory and accounts payable levels.

\section{Do low ratios of inventories and accounts receivable harm profitability?}

We have demonstrated that firms with more limited access to external finances tend to have lower inventory and accounts receivable ratios. We also have shown, in the fixed effects regression, that a given firm lowers these ratios in response to worsening financing conditions. A natural question that arises is whether these effects of limited access to external finance may be harmful to firms because inventory and accounts receivable ratios of financially constrained firms are so low as to prevent them from operating at an optimal level of sales. In fact, both ratios in private firms are even lower than those in foreign invested firms. If we assume that foreign invested firms are both unconstrained financially and efficient at managing their inventory, this may imply that private firms may in fact be reducing their inventory below the optimal level, confirming the suspicion above.

Table 8 shows that this fear may not be justified, as the total and the component inventory days for Chinese private firms (inferred from the inventory data) are all comparable to the average levels in OECD firms in 1994-2004. In contrast, most other types of Chinese firms have longer inventory days, particularly in raw material and intermediate goods inventories. The Chinese private firms are even closer to firms in Japan and Korea, China’s two Asian neighbors. If one uses Korea as a benchmark, the Chinese private firms still have room to further reduce their inventory level. In other words, although much lower than other types of Chinese firms in inventory levels, especially 
Chinese SOEs, Chinese private firms seem to operate within the normal range of inventory levels by international standards. The time coverage difference between the Chinese data and the OECD data further strengthens this argument, as improvements in inventory technologies have led to declining inventory levels over time.

[Table 8 about here]

Table 9 compares Chinese firms with U.S. firms in terms of the accounts receivable/sales ratio. For large firms, Chinese firms have slightly lower account receivables ratios than their American counterparts. Given that U.S. data is from late 1980s while the Chinese data is for this century, and that the accounts receivable/sales ratios tend to decrease over time due to more advanced payment methods, it is reasonable to argue that large firms in the two countries have similar RA/sales ratios. For small firms, Chinese firms have higher average AR/sales ratios than the U.S. firms yet lower median ratios, implying more variation among small Chinese private firms in their ability to recoup sales revenue from customers. As seen before, among large and medium-sized firms, Chinese private firms maintain lower levels of accounts receivable than Chinese SOEs. Overall, there is no clear evidence that Chinese private firms have to maintain overly low RA/sales ratios.

[Table 9 about here]

Yet, to further address the possibility of Chinese private firms carrying levels of inventory and accounts payable that are too low, we now study the potential non-linear effects of inventory and accounts receivable ratios on profitability and productivity of the firms. In Table 10 we show the estimation results of regressing profitability measure (pretax or after-tax return on assets) or total factor productivity measure on the ratios of inventory and accounts receivable to sales and the squares of these ratios. ${ }^{\mathrm{h}}$ If reducing inventories below a certain level has a detrimental effect on 
profitability, we should see a negative coefficient on the square term and positive coefficient on the linear term. As columns 1, 2, 4, and 5 of Table 10 show, for both inventory and accounts receivable the pattern is reversed - the coefficient is positive on the square term and negative on the linear term. Furthermore, the magnitudes of these coefficients indicate that for the entire range of values for both ratios, lower ratios are associated with higher profitability - the minima of both quadratic functions are above the highest value of the ratios in our data. ${ }^{\mathrm{i}}$ The findings related to inventory levels are consistent with Lieberman and Demeester (1999) who studied Japanese car manufacturers, while the results on accounts receivable are in line with those in Fisman (2001).

\section{[Table 10 about here]}

Columns 3 and 6 of Table 10 show that productivity is associated with inventory and accounts receivable ratios in the same way as profitability - for the values of these ratios in our sample, lower ratios are usually associated with higher productivity. The theoretical argument in support of the findings on inventory is outlined in Lieberman and Demeester (1999): As firms have lower inventory levels, problems related to various steps in the production process are more easily exposed and thus are more likely to be resolved by managers and workers, which then leads to increases in firm productivity. As for trade credit, Fisman (2001) argues that greater supplier credit helps firms more fully utilize their capacity. By reducing working capital requirement, a lower accounts receivable level will have similar effects in helping firms reaching their full capacity and thus enhancing productivity. Additionally, the extra funds available may help make new process and technology more affordable, which further enhances productivity. It is worth noting that such an advantage is in addition to the channel of lower financial costs, which is the usually the focus of research. 
Therefore, we find that for large and medium-sized Chinese firms, a) firms with lower inventory and accounts receivable ratios tend to have higher profitability and higher total factor productivity in the crosssection, controlling for industry and ownership type; b) controlling for firm fixed effects, when inventories and accounts receivables fall, firms become more profitable and more productive. To explore the patterns for small private firms, we again turn to the private firm survey data. Panel B presents the corresponding results using the survey data. As before, industry, province, and year dummies are controlled for in the analysis of the repeated cross-sectional data.

Columns 1-3 give estimation results using pretax and after-tax return on assets and a crude measure of total factor productivity as the dependent variable, respectively. ${ }^{j}$ As we can see, just like the results from analyzing the data for the larger firms, the linear term always has negative effects, while the effect of the quadratic term is always positive. For pre-tax return on asset, the coefficient on the linear term of the accounts receivable/sales ratio is the only that has a significant effect, implying that a monotonically negative correlation between accounts receivable and profitability: the lower the accounts receivable to sales ratio, the higher the profitability. Likewise, the results suggest that the relationship between accounts receivable and TFP is exclusively monotonic: the lower the accounts receivable to sales ratio, the higher the firm's TFP. ${ }^{k}$ In addition, the effects of accounts receivable on both profitability and productivity are larger than those obtained for the larger firms. This is suggestive evidence that small private firms benefit more from managing their working capital more efficiently. As small private Chinese firms are the most constrained in their access to external finances, these findings provide more salient support for the argument that more efficient management of working capital (inventory and accounts receivable) may have led to better firm performance, both through lower financial costs and via real productivity gains. 
One additional robustness test to support the argument that lower inventory levels can lead to higher productivity or profitability is the following. Among the different types of inventories, final products inventories are the easiest to change into sales, and thus the best source for higher profitability or productivity (measured on the basis of sales). Thus firms in sectors with a higher proportion of inventories in final products will find it easier to increase productivity and profitability by reducing the level of inventory. We are not aware of any existing indices that rank sectors by their inventory composition, thus we construct our own sector level inventory measures (at CIC 2 digit level averaged over 2000-2006) by focusing on foreign invested firms in China. These firms provide a reasonable standard for how firms allocate inventories without financial constraints. We then include two additional explanatory variables in the analysis above using the balanced panel data: the sector level ratio between final products inventory and total inventory, as well as its interaction with the firm level inventory/sales ratio. As expected, Panel A in Table 11 shows that firms in sectors with more of their inventories in final products indeed find it easier to increase both their profit rate (ROA) and their productivity (TFP), as the interaction term has the same negative sign as the inventory/sales ratio. ${ }^{1}$

Similarly, we include the sector average reliance on trade credit (i.e., the accounts payable/total asset ratio using data from U.S. firms in the 1980s (Fisman and Love 2003) as well as its interaction with accounts receivable/sales as additional explanatory variables to study whether a similar story applies to accounts receivable. The logic is the following: If firms can improve productivity or profitability by reducing accounts receivable, then the sectors with a greater reliance on trade credit overall should find it easier to do so, as there are more opportunities to do so. Thus, we expect a negative sign for the coefficient of the interaction term, same as that of the accounts receivable/sales ratio itself. Results in Panel B of Table 11, as expected, give negative estimates for the effects of the interaction terms, although only the estimates for 
TFP are very close to being significant. Finally, Panel C in Table 11 present results when both interaction terms are included, with the previous findings preserved.

[Table 11 about here]

\section{Conclusion}

It has long been noted in the literature that private firms in China have more limited access to external financing and that such credit constraints are harmful for the development of the private sector in China. Nevertheless, despite limited access to financing, the private sector in China has experienced a long period of strong growth prior to the onset of the global recession. While we cannot fully reconcile these two apparently conflicting observations, we provide evidence that may help explain some of the puzzle. In particular, we show that Chinese private firms respond to financing constraints by lowering inventory and accounts receivable and thus limiting their need for working capital. We further show that even at the low levels of inventory and accounts receivable, reductions in these ratios are associated with higher productivity and profitability. In other words, facing and overcoming financing constraints may have forced Chinese private firms to become more efficient, especially compared to their state-owned counterparts for which easy access to financing seems to lead to inefficiently high levels of inventory and trade credit.

Our findings do not necessarily contradict the argument that limited access to external funding is likely slowing down the development of the private sector in China. In fact because private firms are able to manage working capital very efficiently (by maintaining low levels of inventory and accounts receivable), our results imply that easier access to external finance will likely lead to more expansion and long-term investment projects by private firms. Hence, financial market reforms, by 
allowing further growth of the private sector through more credit availability, may well be the next engine of sustained economic growth in China.

${ }^{a}$ The views expressed in this paper are those of the authors and do not necessarily represent the views of the Federal Reserve Bank of San Francisco or Federal Reserve System. Part of this work was conducted while Hale was visiting the Hong Kong Institute of Monetary Research, for whose hospitality she is most grateful. We thank participants at the 2010 CESifo Summer Institute and 2010 NBER China Working Group Meeting, especially Li Jin and Gunther Schnabl for their comments, and Hirotaka Miura for excellent research assistance. All errors are ours.

${ }^{\mathrm{b}}$ Using a small sample of private firms and SOEs for 1994-1999, Ge and Qiu (2007) provide evidence that private firms use trade credit as a net source of credit (i.e., incur higher accounts payable than accounts receivable), while SOEs on average are a net supplier of trade credit. However, in the more recent years we are focusing on (2000-2006), this channel appears to have dried out.

${ }^{\mathrm{c}}$ While the raw data includes 622,424 firms, after we drop observations with missing values for year, location, industry code, duplicates or near duplicates, as well as observations with key variables that appear erroneously reported or missing, we are left with 496,738 firms in the unbalanced panel data set.

${ }^{\mathrm{d}}$ One may be concerned with the survivorship bias in our balanced panel regression. However, our results also hold in the cross-section, a snapshot of 2006 data, where they cannot be driven by survivorship bias. 
${ }^{\mathrm{e}}$ Note that the per unit cost for external financing computed here is different from average interest rate for at least two reasons: (1) A firm’s total debt may include liabilities not bearing interest payments such as various accounts payable, and (2) Even if the firm's total debt comprises only interest-bearing bank loans, the year-end total debt may not correspond to the amount of bank loans that incurred the interest payment in that year. However, this ratio still gives a proxy for the average cost of obtaining finances faced by firms of different types.

${ }^{\mathrm{f}}$ Repeating Table 6 with LT debt/LT assets instead of leverage largely preserves results in both the cross section and the panel analysis, with the only exception of a small negative effect of state dummy for AR in the cross-section results.

${ }^{\mathrm{g}}$ We are able to estimate the level effect because some firms have changed their industries over time.

${ }^{\mathrm{h}}$ Total factor productivity (TFP) for the panel analysis here is measured as a residual from estimating an industry-by-industry system GMM model of production function. For the detailed description of how these TFP measures are obtained, see Hale, Long, and Miura (2010).

${ }^{\mathrm{i}}$ To be precise, there are 129 observations in the cross-section data and 153 observations in the panel data for which inventory to sales ratio is in the increasing range of the estimated quadratic function. For the accounts receivable there are no observations in the increasing range of the quadratic function.

${ }^{\mathrm{j}}$ Because raw material usage is unknown for firms in the survey data, we construct estimate TFP by running a regression of log sales on log assets and log labor, in addition to variables of interest.

${ }^{\mathrm{k}}$ There are only 17 firms in our sample of small private firms for which the accounts receivable to sales ratio is in the increasing range of the estimated quadratic function. 
${ }^{1}$ The following alternative specifications give similar results, testifying to the robustness of the results: The finish goods/inventory ratio is also computed at the sector-year level, or the inventory/sales ratio and the accounts receivable/sales are computed relative to the sector averages.

\section{References:}

“Investigation Report on Chinese Small and Medium Firm Financial System”, PBOC and JICA (Research Bureau of People’s Bank of China, and Janpan International Cooperation Agency) 2005 Zhongxin Publishing, Beijing.

Allen, Franklin, Jun Qian, and Meijun Qian, 2005, “Law, Finance, and Economic Growth in China,” Journal of Financial Economics, Vol. 77 (July) pp. 57-116.

Allen, Qian, and Qian (2007), "China’s Financial System: Past, Present, and Future" in “The Transition that Worked: Origins, Mechanism, and Consequences of China’s Long Boom,” edited by Loren Brandt, Univ. of Toronto, and Thomas Rawski, Univ. of Pittsburgh.

Bai, Chong-En, Chang-Tai Hsieh, and Yingyi Qian, 2006, “The Return to Capital in China,” NBER Working Paper 12755, December.

Boyreau-Debray, Genevieve and Wei, Shang-Jin, Pitfalls of a State-Dominated Financial System: The Case of China (March 2005). NBER Working Paper No. W1121

Brandt, Loren, and Hongbin Li, 2003. “Bank Discrimination in Transition Economies: Ideology, Information or Incentives?” Journal of Comparative Economics 31. 
Cull, Robert, and Lixin Colin. Xu, 2000, “Bureaucrats, State Banks, and the Efficiency of Credit Allocation: The Experience of Chinese State-Owned Enterprises,” Journal of Comparative Economics, Vol. 28 (March), pp. 1-31.

Cull, Robert, Xu, Lixin Colin, 2003. Who gets credit? The behavior of bureaucrats and state banks in allocating credit to Chinese state-owned enterprises. Journal of Development Economics, 71 (2), 533-559.

Cull, Robert, and Colin Xu, 2005. “Institutions, Ownership, and Finance: The Determinants of Reinvestments of Profit among Chinese Firms,” Journal of Financial Economics 77, 117-146.

Cull, Robert, Lixin Colin Xu, and Tian Zhu (2009), "Formal finance and trade credit during China’s transition", Journal of Financial Intermediation, Vol. 18 (2009) 173-192

Dobson, Wendy, and Anil Kashyap, 2007, “The Contradiction in China's Gradualist Banking Reforms," Brookings Papers on Economic Activity.

Dollar, D., and S. Wei (2007): “Das (wasted) Kapital: Firm Ownership and Investment Efficiency in China,” NBER Working Paper, 13103.

Fisman, Rayman (2001), “Trade Credit and Productive Efficiency in Developing Countries,” World Development, Volume 29, Issue 2, February 2001, Pages 311-321.

Fisman, Raymond, and Inessa Love (2003), “Trade credit, financial intermediary development, and industry growth” Journal of Finance, Volume 58, Issue 1, Pages 353-374.

Ge, Ying, and Jiaping Qiu (2007), "Financial development, bank discrimination and trade credit", Journal of Banking and Finance, Volume 31, Issue 2, February 2007, Pages 513-530. 
Hale, Galina and Cheryl Long (2010), "What are the sources of financing of the Chinese firms?” forthcoming in “The Evolving Role of Asia in Global Finance”, Yin-Wong Cheung, ed.

Hale, Galina, Cheryl Long, Ted Moran, and Hirotaka Miura (2010), “Where to Find Positive Productivity Spillovers from FDI in China: Disaggregated Analysis,” HKIMR Working Paper.

Hèricourt, J., and S. Poncet (2008), “FDI and Credit Constraints: firm level evidence from China”, Economic Systems.

Hsieh, Chang-Tai and Peter J. Klenow (2009), “Misallocation and Manufacturing TFP in China and India,” Quarterly Journal of Economics, CXXIV (4), November.

Huang, Yasheng (2004): Selling China. Cambridge University Press.

King, Robert, and Ross Levine, 1993. “Finance and Growth: Schumpeter Might Be Right,” Quarterly Journal of Economics 108, 717-738.

Lardy, Nicholas R., 2004, “State-Owned Banks in China”, in Gerard Caprio et al, Eds, The Future of State-Owned Financial Institutions, Washington, D.C.: Brookings Institution Press.

Lardy, Nicholas, 1998, China’s Unfinished Economic Revolution (Washington DC: The Brookings Institution).

Li, Kui-Wai, 2003, “China’s Capital and Productivity Measurement Using Financial Resources,” Economic Growth Center, Center Discussion Paper No. 851 (February), Yale University.

Lieberman, Marvin B., Lieven Demeester. 1999. "Inventory reduction and productivity growth: Linkages in the Japanese automotive industry.” Management Science 45(4) 466-485. 
Liu, Qiao and Siu, Alan, Institutions, Financial Development, and Corporate Investment: Evidence from an Implied Return on Capital in China (December 25, 2006). Available at SSRN:

http://ssrn.com/abstract $=965631$

Long, Cheryl and Xiaobo Zhang (2010), “Industrial Clusters and Firm Financing in China” with Xiaobo Zhang. The International Food Policy Research Institute Discussion Papers (IFPRI DP).

Panicos O. Demetriades, Jun Du, Sourafel Girma, Chenggang Xu, 2008, “Does the Chinese Banking System Promote the Growth of Firms?” Working Paper No. 08/6

Park, Albert, and Kaja Sehrt, 2001, “Tests of Financial Intermediation and Banking Reform in China,” Journal of Comparative Economics, Vol. 29 (December), pp. 608-44.

Petersen, Mitchell, Raghuram Rajan, 1997. “Trade credit: Theories and evidence,” Review of Financial Studies 10, 661-691.

Poncet, Sandra, Walter Steingress, and Hylke Vandenbussche, 2008, "Financial constraints in China: firm-level evidence" LICOS Discussion Paper 226/2008.

Rajan, R. G., and L. Zingales (1998), “Financial dependence and growth,” American Economic Review, 88, pp. 559-586.

Roumiantsev, Serguei and Serguei Netessine (2007), “Inventory and its relationship with profitability: evidence for an international sample of countries” Wharton Working Paper. 
Table 1. Firm distribution by de facto and de jure ownership type

\section{6 census cross-section}

\begin{tabular}{l|ccccccc}
\hline \multirow{2}{*}{$\begin{array}{l}\text { De facto } \\
\text { ®wnership }\end{array}$} & state & private & collective & frn* & hmt* & other & Total \\
\hline state & 12,309 & 37 & 46 & 325 & 262 & 2,807 & 15,786 \\
private & 104 & 111,610 & 862 & 2,054 & 1,600 & 27,843 & 144,073 \\
collective & 100 & 378 & 10,556 & 354 & 344 & 4,324 & 16,056 \\
frn* & 2 & 112 & 3 & 21,976 & 251 & 173 & 22,517 \\
hmt* & 3 & 102 & 9 & 380 & 21,220 & 155 & 21,869 \\
Legal person & 2,754 & 35,962 & 2,736 & 5,898 & 5,081 & 23,590 & 76,021 \\
Other** & 55 & 136 & 48 & 304 & 237 & 563 & 1,343 \\
Total & 15,327 & 148,337 & 14,260 & 31,291 & 28,995 & 59,455 & 297,665 \\
\hline
\end{tabular}

Number of firms reported in each cell

\section{Balanced panel}

De facto

De jure ownership

\begin{tabular}{l|lllllll|} 
ownership & state & private & collective & $\mathrm{frn}^{*}$ & $\mathrm{hmt}^{*}$ & other & Total \\
\hline state & 47,702 & 105 & 475 & 1,116 & 1,373 & 6,119 & 56,890 \\
private & 614 & 36,098 & 3,532 & 1,489 & 1,700 & 28,094 & 71,527 \\
collective & 847 & 1,114 & 21,924 & 1,262 & 1,852 & 7,684 & 34,683 \\
$\mathrm{frn}^{*}$ & 20 & 55 & 67 & 23,169 & 2,400 & 124 & 25,835 \\
$\mathrm{hmt}^{*}$ & 20 & 126 & 146 & 1,955 & 24,117 & 129 & 26,493 \\
person & 6,457 & 10,576 & 5,014 & 5,223 & 6,478 & 18,976 & 52,724 \\
Other** & 229 & 143 & 320 & 605 & 616 & 1,661 & 3,574 \\
Total & 55,889 & 48,217 & 31,478 & 34,819 & 38,536 & 62,787 & 271,726 \\
\hline
\end{tabular}

Number of observations reported in each cell. Number of firms = Number of observations/7

*frn = owned by foreign company with headquarters outside greater China area; hmt = owned by a company with headquarters in Hong Kong, Taiwan, or Macao

**Firms where no single ownership category holds more than 50\% shares

Table 2. Mean leverage, financial and interest expense ratios 
Mean (leverage $=$ total debt/total asset)

\begin{tabular}{|c|c|c|c|c|c|c|c|}
\hline year & other & state & private & $\begin{array}{c}\text { ownership } \\
\text { collective }\end{array}$ & frn & hmt & legal person \\
\hline \multicolumn{8}{|c|}{ Census full 2006 cross-section } \\
\hline 2006 & 0.5270655 & 0.5599121 & 0.553948 & 0.5386975 & 0.4697204 & 0.4761098 & 0.5285534 \\
\hline \multicolumn{8}{|c|}{ Balanced panel (census) } \\
\hline 2000 & 0.5710869 & 0.5670198 & 0.6224115 & 0.5974506 & 0.4732248 & 0.4957071 & 0.5716565 \\
\hline 2001 & 0.5544248 & 0.5608889 & 0.6144733 & 0.5874439 & 0.4538752 & 0.4808093 & 0.5670505 \\
\hline 2002 & 0.5453331 & 0.560621 & 0.6097414 & 0.5812743 & 0.4499532 & 0.476328 & 0.5667261 \\
\hline 2003 & 0.5496885 & 0.5594965 & 0.6095757 & 0.5767031 & 0.4514101 & 0.4746216 & 0.5639201 \\
\hline 2004 & 0.530387 & 0.5657067 & 0.6089812 & 0.5675425 & 0.4678842 & 0.4648331 & 0.5735869 \\
\hline 2005 & 0.5280951 & 0.5678059 & 0.5967634 & 0.56247 & 0.4527427 & 0.4704356 & 0.5616242 \\
\hline 2006 & 0.5404513 & 0.5653585 & 0.5895072 & 0.559625 & 0.4463859 & 0.4695703 & 0.556495 \\
\hline
\end{tabular}

Survey data (private firms only)

\begin{tabular}{l|cc|}
\hline year & debt/asset & debt/asset1 \\
\hline 2000 & 0.1711667 & . \\
2002 & 0.1769443 & 0.2110109 \\
2004 & 0.1838394 & 0.223089 \\
2006 & 0.2167257 & 0.24843 \\
\hline
\end{tabular}

Where asset does not include accounts receivable, but asset1 includes AR (which was not available for 2000).

Mean (financial expense/total expense)

\begin{tabular}{|c|c|c|c|c|c|c|c|}
\hline year & other & state & private & $\begin{array}{c}\text { ownership } \\
\text { collective }\end{array}$ & frn & hmt & legal person \\
\hline \multicolumn{8}{|c|}{ Census full 2006 cross-section } \\
\hline 2006 & 0.0255374 & 0.0457006 & 0.0152922 & 0.0176842 & 0.0148726 & 0.0122669 & 0.0204316 \\
\hline \multicolumn{8}{|c|}{ Balanced panel (census) } \\
\hline 2000 & 0.0445738 & 0.0632555 & 0.0279436 & 0.0320019 & 0.0301418 & 0.0191012 & 0.0403799 \\
\hline 2001 & 0.0407172 & 0.0623533 & 0.0269873 & 0.0304421 & 0.0275245 & 0.0170225 & 0.0376548 \\
\hline 2002 & 0.041142 & 0.0593192 & 0.0243659 & 0.0286642 & 0.0235307 & 0.0144496 & 0.0370419 \\
\hline 2003 & 0.0341271 & 0.0572678 & 0.0225671 & 0.0263405 & 0.0215939 & 0.0138601 & 0.0324943 \\
\hline 2004 & 0.0340242 & 0.0550491 & 0.0230045 & 0.0223288 & 0.0175288 & 0.0125677 & 0.0315693 \\
\hline 2005 & 0.0287277 & 0.0504006 & 0.0217918 & 0.0226448 & 0.0155942 & 0.0132149 & 0.0297987 \\
\hline 2006 & 0.0300134 & 0.0496973 & 0.0216176 & 0.0204176 & 0.0159484 & 0.0151862 & 0.0273304 \\
\hline
\end{tabular}


Mean (interest expense/total debt)

\begin{tabular}{|c|c|c|c|c|c|c|c|}
\hline year & other & state & private & $\begin{array}{c}\text { ownership } \\
\text { collective }\end{array}$ & frn & hmt & legal person \\
\hline \multicolumn{8}{|c|}{ Census full 2006 cross-section } \\
\hline 2006 & 0.0266667 & 0.0157521 & 0.0307337 & 0.0249302 & 0.0146456 & 0.0122944 & 0.0289223 \\
\hline \multicolumn{8}{|c|}{ Balanced panel (census) } \\
\hline 2000 & 0.0316954 & 0.0220281 & 0.0330856 & 0.035588 & 0.0228914 & 0.0172136 & 0.0316134 \\
\hline 2001 & 0.032206 & 0.0208976 & 0.0320514 & 0.033084 & 0.0202682 & 0.0162542 & 0.0296349 \\
\hline 2002 & 0.0271391 & 0.0197437 & 0.0298703 & 0.0319305 & 0.0173067 & 0.0154289 & 0.03086 \\
\hline 2003 & 0.0249439 & 0.0191362 & 0.0288501 & 0.0301492 & 0.0147266 & 0.0141237 & 0.0285463 \\
\hline 2004 & 0.0232134 & 0.0174312 & 0.0294332 & 0.026364 & 0.0139089 & 0.0127125 & 0.0267188 \\
\hline 2005 & 0.0229547 & 0.0167197 & 0.0302106 & 0.027168 & 0.0151674 & 0.0137857 & 0.0273302 \\
\hline 2006 & 0.0263176 & 0.0158902 & 0.030519 & 0.0252377 & 0.0155676 & 0.0127305 & 0.0263805 \\
\hline
\end{tabular}

Table 3. OLS regressions in the 2006 NBS census cross-section

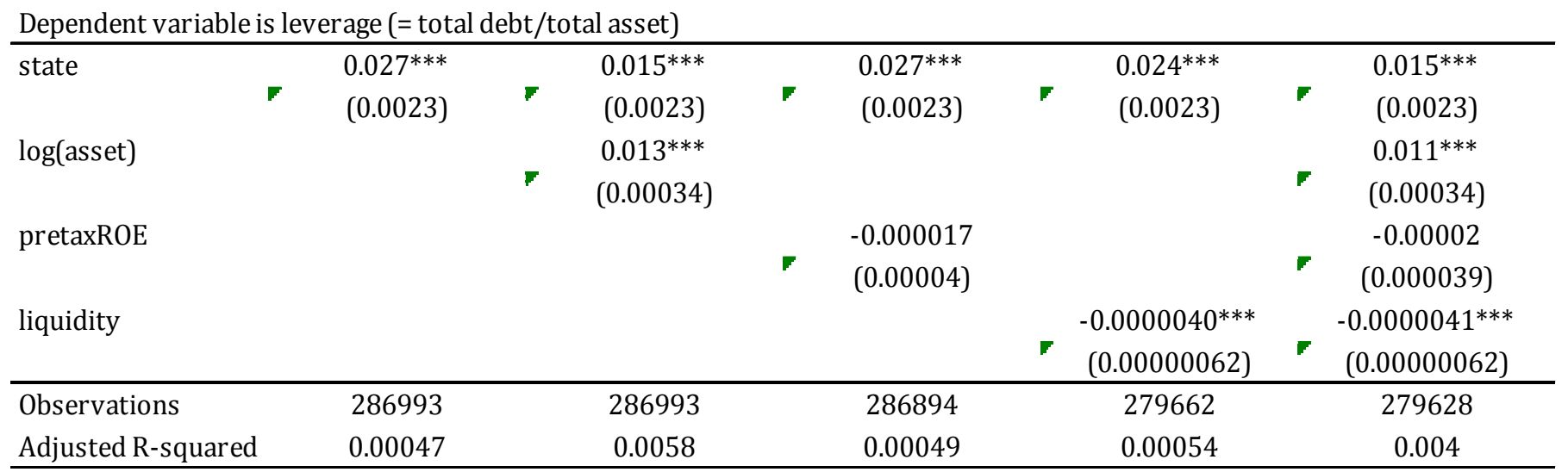

Dependent variable is LT debt/LT assets

\begin{tabular}{|c|c|c|c|c|c|}
\hline \multirow[t]{2}{*}{ state } & $0.11^{* * *}$ & $0.094^{* * *}$ & $0.11^{* * *}$ & $0.11^{* * *}$ & $0.095^{* * *}$ \\
\hline & -0.0014 & -0.0014 & -0.0014 & -0.0014 & -0.0014 \\
\hline \multirow[t]{2}{*}{$\log ($ asset) } & & $0.019^{* * *}$ & & & $0.019^{* * *}$ \\
\hline & & -0.00021 & & & -0.00022 \\
\hline \multirow[t]{2}{*}{ pretaxROE } & & & $2.9 \mathrm{E}-06$ & & $-3.9 \mathrm{E}-06$ \\
\hline & & & $-2.5 E-05$ & & $-2.5 \mathrm{E}-05$ \\
\hline \multirow[t]{2}{*}{ liquidity } & & & & $-2.8 \mathrm{E}-07$ & $-4.9 \mathrm{E}-07$ \\
\hline & & & & $-4 \mathrm{E}-07$ & $-4 \mathrm{E}-07$ \\
\hline Observations & 289883 & 289883 & 289780 & 282840 & 282802 \\
\hline Adjusted R-square & 0.021 & 0.045 & 0.021 & 0.021 & 0.047 \\
\hline
\end{tabular}




\begin{tabular}{|c|c|c|c|c|c|}
\hline state & $\begin{array}{l}0.029^{* * *} \\
(0.00042)\end{array}$ & $\begin{array}{l}0.024^{* * *} \\
(0.00042)\end{array}$ & $\begin{array}{l}0.029^{* * *} \\
(0.00042)\end{array}$ & $\begin{array}{l}0.029^{* * *} \\
(0.00043)\end{array}$ & $\begin{array}{l}0.024^{* * *} \\
(0.00042)\end{array}$ \\
\hline $\log$ (asset) & & $\begin{array}{l}0.0062^{* * *} \\
(0.000062)\end{array}$ & & & $\begin{array}{c}0.0062^{* * *} \\
(0.000063)\end{array}$ \\
\hline pretaxROE & & & $\begin{array}{c}0.0000032 \\
(0.0000072)\end{array}$ & & $\begin{array}{c}0.0000015 \\
(0.0000071)\end{array}$ \\
\hline liquidity & & & & $\begin{array}{r}-0.000000079 \\
(0.00000014) \\
\end{array}$ & $\begin{array}{c}-0.00000015 \\
(0.00000013) \\
\end{array}$ \\
\hline Observations & 265672 & 265670 & 265630 & 258509 & 258472 \\
\hline Adjusted R-squared & 0.018 & 0.052 & 0.018 & 0.018 & 0.053 \\
\hline
\end{tabular}

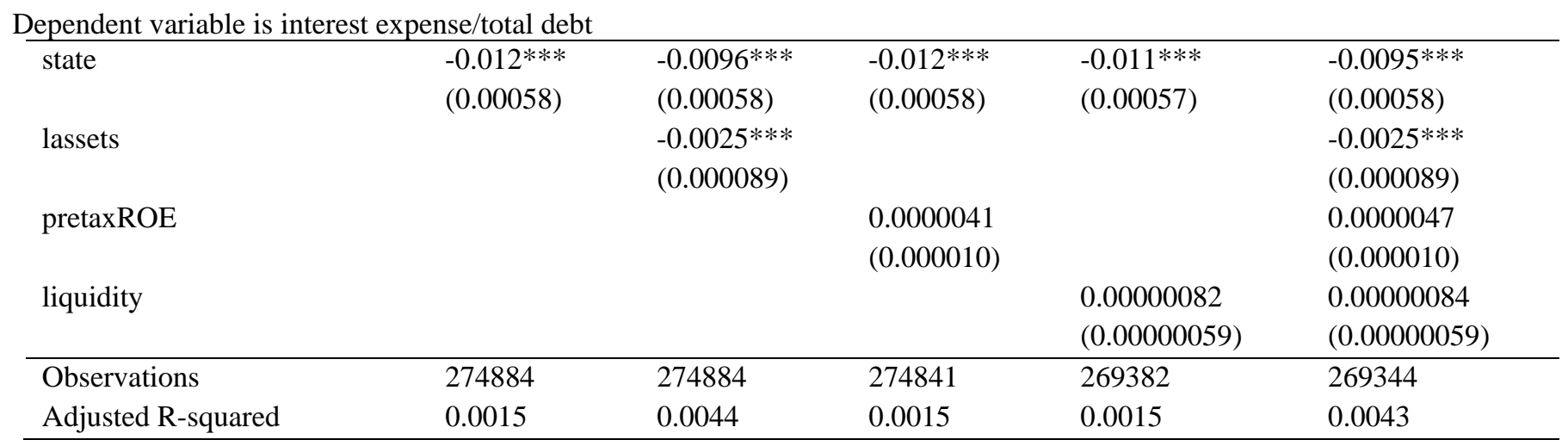

Note: liquidity $=($ short-term asset - short-term debt $) /$ short-term debt

Table 4. Balanced panel census GLS RE regressions

\begin{tabular}{|c|c|c|c|c|}
\hline & leverage & LT debt/LT assets & finexp & int_rate \\
\hline \multirow[t]{2}{*}{ state } & $-0.039 * * *$ & $0.039 * * *$ & $0.019 * * *$ & $-0.0027 * * *$ \\
\hline & $(0.0019)$ & $(0.0018)$ & $(0.00060)$ & $(0.00047)$ \\
\hline \multirow[t]{2}{*}{ State*time trend } & $0.011^{* * *}$ & $0.0031^{* * *}$ & $-0.0011^{* * *}$ & $-0.00028 * * *$ \\
\hline & $(0.00034)$ & $(0.0003)$ & $(0.00011)$ & $(0.000093)$ \\
\hline \multirow[t]{2}{*}{ Log(asset) } & $0.018 * * *$ & $0.022^{* * *}$ & $0.0070 * * *$ & $-0.0024 * * *$ \\
\hline & $(0.00053)$ & $(0.0004)$ & $(0.00015)$ & $(0.00010)$ \\
\hline \multirow[t]{2}{*}{ pretaxROE } & -0.0000026 & 0.000016 & 0.0000033 & 0.0000052 \\
\hline & $(0.000019)$ & $(0.000019)$ & $(0.0000061)$ & $(0.0000050)$ \\
\hline
\end{tabular}




\begin{tabular}{lcccc}
\hline liquidity & -0.00000024 & $-1.4 \mathrm{e}-07$ & $4.8 \mathrm{e}-09$ & $5.8 \mathrm{e}-09$ \\
& $(0.00000019)$ & $(1.9 \mathrm{e}-07)$ & $(0.000000060)$ & $(0.000000052)$ \\
Time trend & $-0.0054^{* * *}$ & $-0.007^{* * *}$ & $-0.0025^{* * *}$ & $-0.00060^{* * *}$ \\
& $(0.00015)$ & $(0.0002)$ & $(0.000051)$ & $(0.000042)$ \\
\hline Observations & 250261 & 254770 & 230893 & 237803 \\
No. of firms & 38320 & 38691 & 37978 & 38312 \\
Within R-squared & 0.13 & 0.009 & 0.19 & 0.04 \\
\hline
\end{tabular}

Note: liquidity $=($ short-term asset - short-term debt $) /$ short-term debt

$\underline{\text { Table 5. Average inventory/sales and AR/sales ratios by ownership in } 2006 \text { census cross-section }}$

\begin{tabular}{lcc} 
ownership & mean (inventory/sales) & mean (AR/sales) \\
\hline Census (2006 cross-section) & & \\
\hline state & 0.3058309 & 0.1607052 \\
private & 0.1384788 & 0.1313267 \\
collective & 0.1708645 & 0.164984 \\
frn & 0.1947837 & 0.1656279 \\
hmt & 0.2216497 & 0.1730874 \\
legal person & 0.172007 & 0.1335646 \\
other & 0.2210449 & 0.1720792 \\
\hline Survey (2006) & & 0.1583272 \\
\hline
\end{tabular}

Table 6. Relationship between inventory/sales and ar/sales ratios and measures of financial constraints

A. 2006 cross-section. 2-digit industry and ownership dummies included but not reported (39 industries)

\begin{tabular}{|c|c|c|c|c|}
\hline & (1) & (2) & (3) & (4) \\
\hline & \multicolumn{4}{|c|}{ dependent variable $=$ inventory $/$ sales ratio } \\
\hline \multirow[t]{2}{*}{ leverage } & $0.13^{* * *}$ & & & $0.091^{* * *}$ \\
\hline & $(0.0023)$ & & & $(0.0025)$ \\
\hline financial expense & & $1.27^{* * *}$ & & $1.22^{* * *}$ \\
\hline /total expense & & $(0.014)$ & & $(0.015)$ \\
\hline per unit & & & $-0.29 * * *$ & $-0.29 * * *$ \\
\hline borrowing cost & & & $(0.0098)$ & $(0.0093)$ \\
\hline Observations & 257719 & 239551 & 247052 & 226218 \\
\hline Adjusted R-squared & 0.047 & 0.068 & 0.042 & 0.075 \\
\hline
\end{tabular}




\begin{tabular}{|c|c|c|c|c|}
\hline & (1) & $(2)$ & (3) & $(4)$ \\
\hline & \multicolumn{4}{|c|}{ dependent variable $=\mathrm{AR} /$ sales ratio } \\
\hline \multirow[t]{2}{*}{ leverage } & $0.084^{* * *}$ & & & $0.070^{* * *}$ \\
\hline & $(0.0012)$ & & & $(0.0013)$ \\
\hline financial expense & & $0.37^{* * *}$ & & $0.40 * * *$ \\
\hline /total expense & & $(0.0075)$ & & $(0.0081)$ \\
\hline per unit & & & $-0.23^{* * *}$ & $-0.20 * * *$ \\
\hline borrowing cost & & & $(0.0047)$ & $(0.0048)$ \\
\hline Observations & 254494 & 236546 & 243788 & 223612 \\
\hline Adjusted R-squared & 0.094 & 0.086 & 0.085 & 0.11 \\
\hline
\end{tabular}

B. Balanced panel with firm and year fixed effects

\begin{tabular}{|l|c|c|c|c|c|}
\hline & $(1)$ & $(2)$ & $(3)$ & $(4)$ & $(5)$ \\
\hline & \multicolumn{4}{|c|}{ dependent variable = inventory/sales ratio } \\
\hline leverage & $0.10^{* * *}$ & & & $0.057^{* * *}$ & $0.062^{* * *}$ \\
\hline & $(0.0042)$ & & & $(0.0046)$ & $(0.005)$ \\
\hline financial expense & & $1.14^{* * *}$ & & $1.16^{* * *}$ & $1.13^{* * *}$ \\
\hline /total expense & & $(0.015)$ & & $(0.016)$ & $(0.018)$ \\
\hline per unit & & & $-0.17^{* * *}$ & $-0.36^{* * *}$ & $-0.31^{* * *}$ \\
\hline borrowing cost & & & $(0.018)$ & $(0.016)$ & $(0.018)$ \\
\hline Growth rate of sales & & & & & $9.9 \mathrm{e}-07$ \\
\hline & & & & & $(2.8 \mathrm{e}-06)$ \\
\hline Observations & 257304 & 237809 & 243552 & 220436 & 187955 \\
\hline Number of firms & 38315 & 37989 & 38298 & 37180 & 36772 \\
\hline Within R-squared & 0.03 & 0.03 & 0.004 & 0.03 & 0.03 \\
\hline
\end{tabular}

\begin{tabular}{|l|c|c|c|c|c|}
\hline & $(1)$ & $(2)$ & $(3)$ & $(4)$ & $(5)$ \\
\hline \multicolumn{5}{|l|}{ dependent variable = AR/sales ratio } \\
\hline leverage & $0.058^{* * *}$ & & & $0.041^{* * *}$ & $0.044^{* * *}$ \\
\hline & $(0.0019)$ & & & $(0.0021)$ & $(0.0023)$ \\
\hline financial expense & & $0.30^{* * *}$ & & $0.34^{* * *}$ & $0.33^{* * *}$ \\
\hline /total expense & & $(0.0068)$ & & $(0.0077)$ & $(0.0084)$ \\
\hline per unit & & & $-0.11^{* * *}$ & $-0.14^{* * *}$ & $-0.13^{* * *}$ \\
\hline borrowing cost & & & $(0.0070)$ & $(0.0073)$ & $(0.0078)$ \\
\hline Growth rate of sales & & & & & $2.02 \mathrm{e}-06$ \\
\hline \multicolumn{2}{|c|}{} & & & & $(1.4 \mathrm{e}-06)$ \\
\hline Observations & 251338 & 231876 & 237267 & 215400 & 183922 \\
\hline Number of firms & 38175 & 37834 & 38145 & 37004 & 36559 \\
\hline Within R-squared & 0.02 & 0.02 & 0.01 & 0.03 & 0.03 \\
\hline
\end{tabular}


C. Repeated cross-section using survey data. Year, 1-digit industry, and ownership dummies included but not reported (19 industries)

\begin{tabular}{lccc}
\hline & $(1)$ & $(2)$ & $(3)$ \\
& \multicolumn{3}{l}{ dependent variable $=$ AR/sales ratio } \\
\hline leverage & $0.13^{* * *}$ & & $0.24^{* *}$ \\
& $(0.024)$ & & $(0.10)$ \\
interest rate & & -0.0036 & -0.0035 \\
& & $(0.0037)$ & $(0.0037)$ \\
\hline Observations & 6287 & 727 & 658 \\
Adjusted R-squarec & 0.019 & 0.082 & 0.2 \\
\hline
\end{tabular}

Table 7: Robustness tests for relationship between financial constraints and inventory (AR) ratios

Panel A: Using sector adjusted inventory \& AR ratios

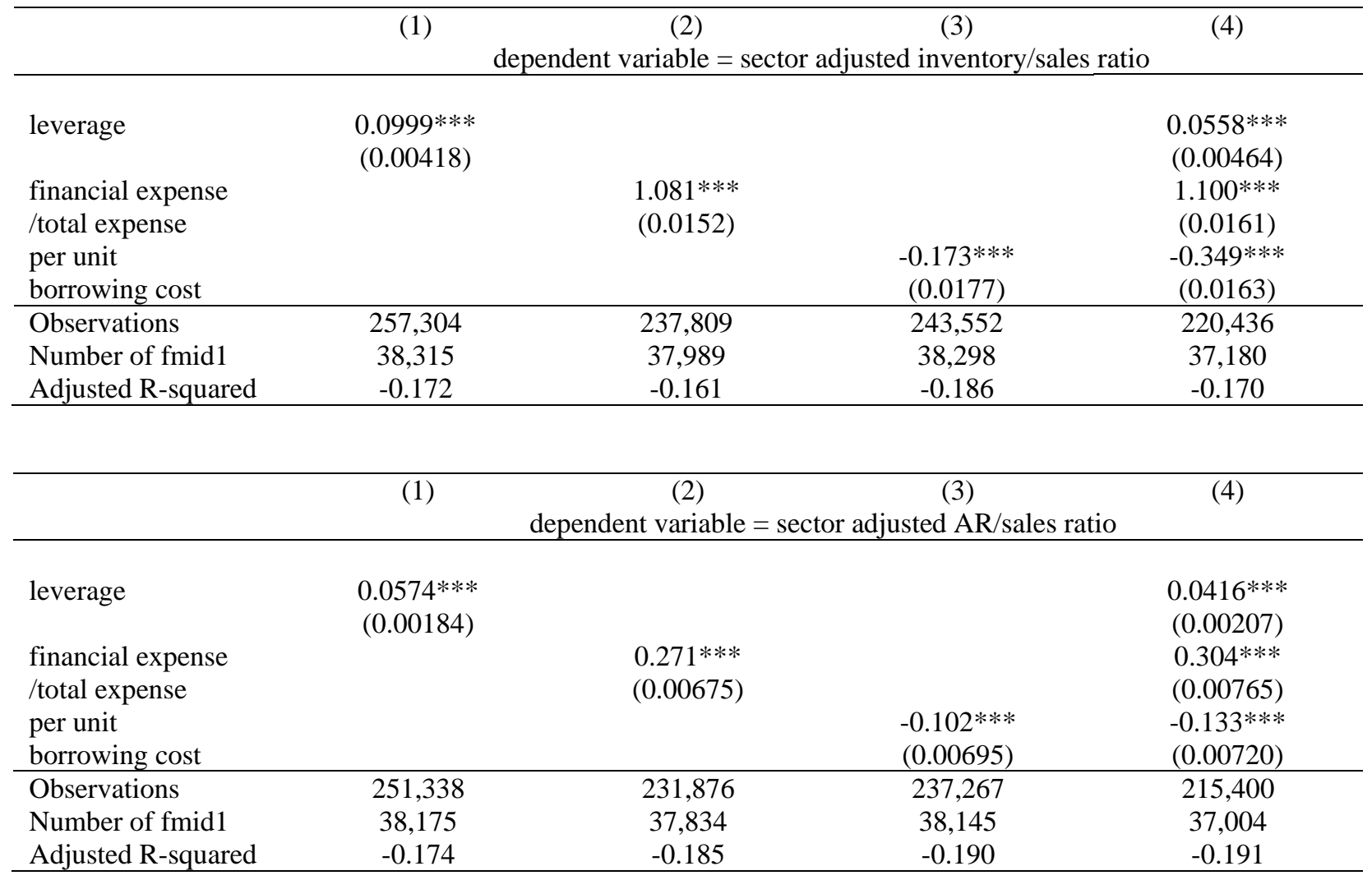

Panel B. Lagged independent variables 


\begin{tabular}{|c|c|c|c|c|}
\hline & (1) & (2) & (3) & (4) \\
\hline & \multicolumn{4}{|c|}{ dependent variable $=$ inventory/sales ratio } \\
\hline Leverage (1 year lag) & $\begin{array}{c}0.024 * * * \\
(0.0046)\end{array}$ & & & $\begin{array}{c}0.0100 * \\
(0.0052)\end{array}$ \\
\hline financial expense & & $0.38^{* * *}$ & & $0.41^{* * *}$ \\
\hline /total expense (1 year lag) & & $(0.017)$ & & $(0.018)$ \\
\hline per unit & & & $-0.043 * *$ & $-0.12^{* * *}$ \\
\hline borrowing cost (1 year lag) & & & $(0.019)$ & $(0.018)$ \\
\hline $\mathrm{N}$ & 221001 & 204252 & 208785 & 189834 \\
\hline Number of firms & 38241 & 37827 & 38194 & 36920 \\
\hline \multirow[t]{3}{*}{ Within R-squared } & 0.002 & 0.006 & 0.003 & 0.006 \\
\hline & (1) & (2) & (3) & (4) \\
\hline & \multicolumn{4}{|c|}{ dependent variable $=\mathrm{AR} /$ sales ratio } \\
\hline Leverage (1 year lag) & $\begin{array}{c}0.0031 \\
(0.0020)\end{array}$ & & & $\begin{array}{c}-0.0036 \\
(0.0023)\end{array}$ \\
\hline financial expense & & $0.14 * * *$ & & $0.15^{* * *}$ \\
\hline /total expense (1 year lag) & & $(0.0072)$ & & $(0.0082)$ \\
\hline per unit & & & $-0.015 * *$ & $-0.049 * * *$ \\
\hline borrowing cost (1 year lag) & & & $(0.0074)$ & $(0.0077)$ \\
\hline $\mathrm{N}$ & 216091 & 199396 & 203659 & 185671 \\
\hline Number of firms & 38085 & 37630 & 38009 & 36729 \\
\hline Within R-squared & 0.010 & 0.015 & 0.012 & 0.014 \\
\hline
\end{tabular}

Panel C: Interacting w/ sector dependence on external financing

\begin{tabular}{|c|c|c|c|c|}
\hline & \multirow[t]{2}{*}{ (1) } & $(2)$ & (3) & \multirow[t]{2}{*}{$(4)$} \\
\hline & & \multicolumn{2}{|c|}{ dependent variable $=$ inventory/sales ratio } & \\
\hline reliance on & -0.0458 & $-0.0736^{* *}$ & $-0.0716^{* *}$ & -0.0456 \\
\hline external financing (1) & $(0.0301)$ & $(0.0346)$ & $(0.0357)$ & $(0.0341)$ \\
\hline leverage (2) & $0.0934 * * *$ & & & $0.0542 * * *$ \\
\hline & $(0.0113)$ & & & $(0.0124)$ \\
\hline$(1) *(2)$ & 0.0328 & & & 0.0351 \\
\hline & $(0.0202)$ & & & $(0.0229)$ \\
\hline financial expense & & $1.789 * * *$ & & $1.967 * * *$ \\
\hline /total expense (3) & & $(0.0535)$ & & $(0.0594)$ \\
\hline$(1)^{*}(3)$ & & $0.256 * * *$ & & -0.00211 \\
\hline & & $(0.0905)$ & & $(0.0998)$ \\
\hline per unit & & & $-0.132 * * *$ & $-0.262 * * *$ \\
\hline borrowing cost(4) & & & $(0.0437)$ & $(0.0386)$ \\
\hline$(1) *(4)$ & & & -0.0454 & $-0.319 * * *$ \\
\hline & & & $(0.0967)$ & $(0.0865)$ \\
\hline Observations & 116,145 & 107,120 & 110,398 & 98,445 \\
\hline
\end{tabular}




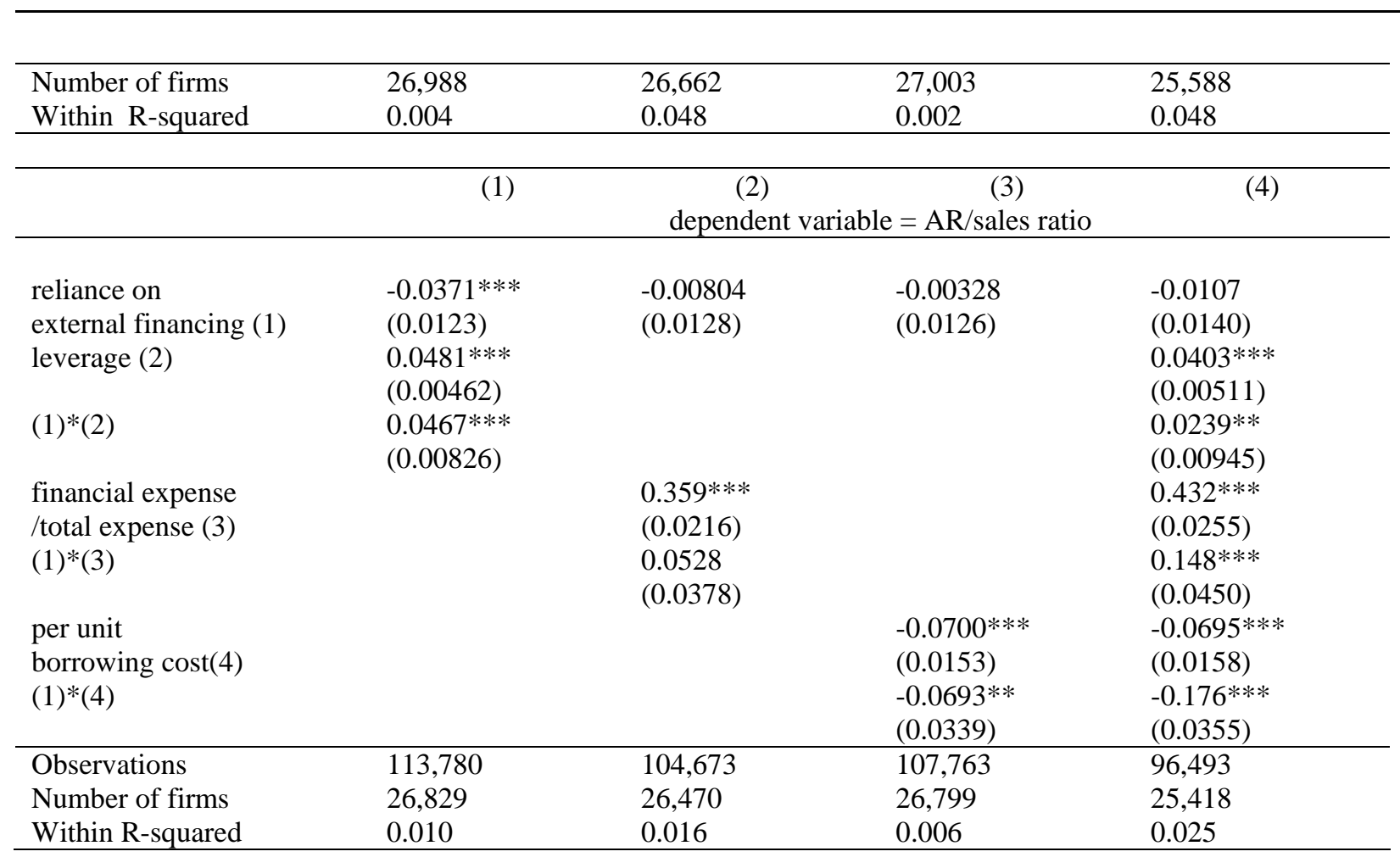

Note: We are able to estimate the level effects because some firms change their industries over time.

Table 8: Comparing Chinese firms with OECD firms in inventory level (days)

\begin{tabular}{lccc} 
firms & $(2000-2006)$ & Finished goods inventory & goods inventory \\
\hline private & 53.3 & 26.1 & 27.2 \\
Hmt & 92.7 & 36 & 56.7 \\
foreign & 82.3 & 31.1 & 51.2 \\
SOE & 189 & 89.9 & 99.9 \\
Mixed & 110.6 & 54.2 & 56.5 \\
& $(1994-2004)$ & & \\
Canada & 74 & 36 & 38 \\
France & 103 & 61 & 42 \\
Germany & 92 & 58 & 34 \\
Britain & 78 & 41 & 37 \\
Japan & 56 & 31 & 25 \\
Korea & 42 & 19 & 23 \\
Switzerland & 93 & 41 & 52 \\
Netherlands & 83 & 51 & 32 \\
U.S. & 82 & 36 & 46 \\
Total & 63 & 34 & 29 \\
\hline
\end{tabular}


Sources: Inventory days for Chinese firms are the authors' own calculations based on the NBS data (2000-2006), (where inventory days = inventory/ sales * 365 days), while those for the OECD country firms during the period of 1994-2004 are from Table 1 in Roumiantsev and Netessine (2007), which are in turn summary statistics of active companies from 9 OECD countries that are included in the COMPUSTAT Global database and that operate in the manufacturing, wholesale and retail, and minerals and mining sectors excluding construction.

Table 9: Comparing Chinese firms with OECD firms in accounts receivable to sales ratio (percent)

Panel A: large firms

\begin{tabular}{|c|c|c|c|c|c|c|c|c|}
\hline & \multirow{2}{*}{\multicolumn{2}{|c|}{$\begin{array}{c}\text { U.S. firms } \\
(1988-1989)\end{array}$}} & \multicolumn{6}{|c|}{ Chinese firms (2006 cross-section) } \\
\hline & & & \multicolumn{2}{|c|}{ private } & \multicolumn{2}{|c|}{ SOE } & \multicolumn{2}{|c|}{ all } \\
\hline & Mean & Median & mean & median & Mean & median & mean & median \\
\hline Mining & 28.7 & 21.7 & 7.7 & 2.2 & 12.6 & 6.1 & 8.8 & 2.8 \\
\hline Construction & 15.8 & 16.4 & & & & & & \\
\hline Manufacturing & 19.1 & 17 & 13.1 & 7.6 & 18 & 11.1 & 14.1 & 8.3 \\
\hline transportation/utilities & 16.2 & 14.1 & 11.3 & 5.6 & 12.2 & 5.1 & 12.3 & 7.8 \\
\hline Wholesale trade & 15.5 & 14 & & & & & & \\
\hline retail trade & 7.3 & 2.3 & & & & & & \\
\hline Services & 22.4 & 19.4 & & & & & & \\
\hline Total & 18.5 & 16.1 & 12.8 & 7.2 & 15.6 & 8.5 & 13.8 & 7.9 \\
\hline
\end{tabular}

Panel B: small firms

U.S. firms
$(1988-1989)$

\begin{tabular}{l|cccc} 
& \multicolumn{3}{c}{ private } \\
& Mean & Median & mean & median \\
\hline Mining & 9.9 & 6.9 & 14.8 & 0.05 \\
Construction & 10.4 & 7.8 & 19.6 & 0.09 \\
Manufacturing & 11.8 & 10 & 16.3 & 0.07 \\
transportation/utilities & 8.1 & 6.5 & 16 & 0.02 \\
Wholesale trade & 8.1 & 7 & & \\
retail trade & 3 & 0.4 & 6.7 & 0 \\
Services & 8 & 3.5 & 9 & 0 \\
Total & 4.4 & 1.8 & 13.6 & 0.03 \\
\hline
\end{tabular}

Source: Information on Chinese firms are the authors' own calculations based on the NBS data (2000-2006, for the large firm sample) and the private firm survey data (2002-2006, for the small firm sample), while that on U.S. firms is from Table 1 in Petersen and Rajan (1997), which in turn summarizes data from the National Survey of Small Business Finances in 1988-1989 for small firms and the Compustat for the large firms.

Table 10: Relationship between inventory and AR ratios and firm performance

A. Census data. 


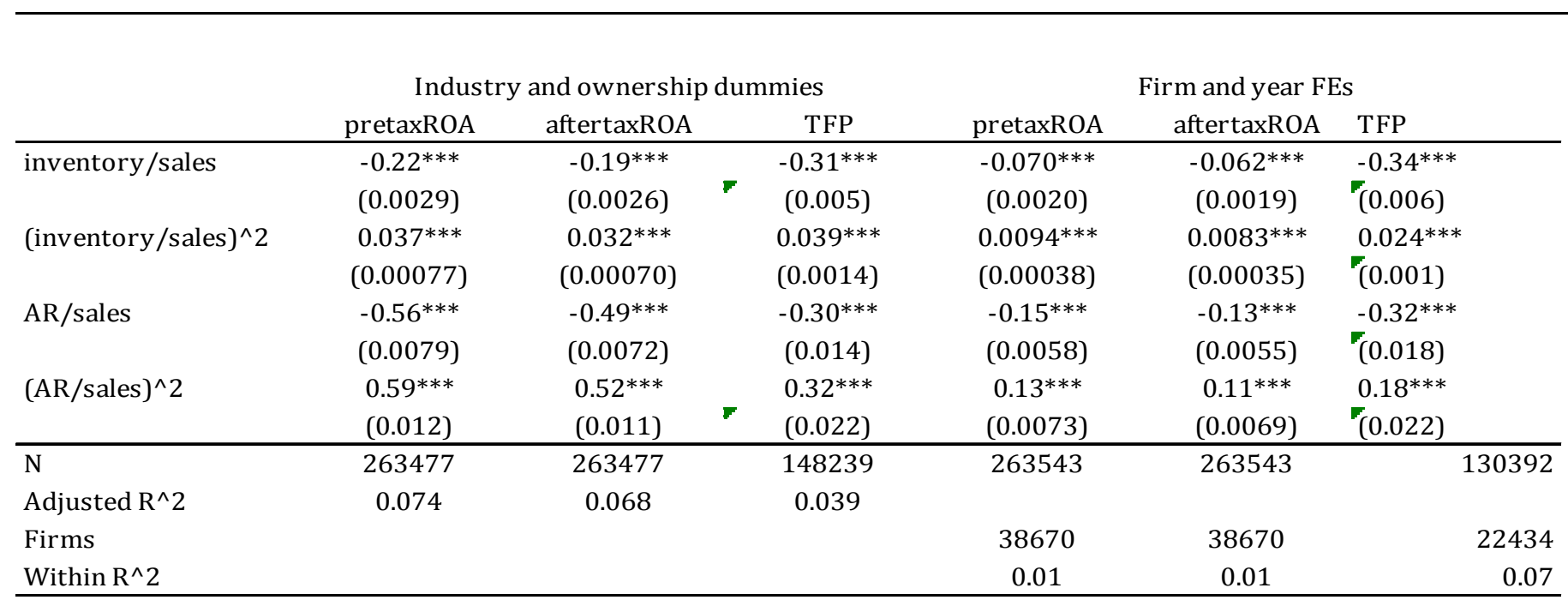

2-digit industry dummies (39 industries in ROA and 31 industries in TFP regressions) are included in cross-section regression, but not reported.

B. Repeated cross-section using survey data. Year, 1-digit industry, and ownership dummies included but not reported (19 industries)

\begin{tabular}{lccc}
\hline & pretaxROA & aftertaxROA & $\log ($ sales $)$ \\
\hline AR/sales & $-0.36^{*}$ & -0.12 & $-1.10^{* * *}$ \\
& $(0.21)$ & $(0.098)$ & $(0.05)$ \\
$(\mathrm{AR} /$ sales)^2 & 0.033 & 0.0098 & $0.078^{* * *}$ \\
& $(0.026)$ & $(0.012)$ & $(0.006)$ \\
$\log ($ employment) & & & $0.48^{* * *}$ \\
& & & $(0.014)$ \\
$\log ($ asset$)$ & & & $0.54^{* * *}$ \\
& & 5887 & $0.012)$ \\
\hline Observations & 4633 & 0.0085 & 0.7 \\
Adjusted R-squared & 0.002 & & \\
\hline
\end{tabular}

Table 11: Robustness tests for relationship between inventory and AR ratios and firm performance

\begin{tabular}{llll}
\hline & $(1)$ & $(2)$ & $(3)$ \\
VARIABLES & pretaxROA & $\begin{array}{l}\text { aftertaxROA } \\
\text { Panel } \boldsymbol{A}\end{array}$ & $\begin{array}{l}\text { TFP } \\
\text { Inventory/sales (1) }\end{array}$ \\
& $-0.0151^{* * *}$ & $-0.0136^{* * *}$ & $-0.193^{* * *}$ \\
AR/sales (2) & $(0.00354)$ & $(0.00334)$ & $(0.00954)$ \\
& $-0.0623^{* * *}$ & $-0.0520^{* * *}$ & $-0.207^{* * *}$ \\
Finished goods inventory & $(0.00245)$ & $(0.00231)$ & $(0.00768)$ \\
/total inventory (3) & 0.00231 & 0.00198 & $0.0543^{* *}$ \\
$(1) *(3)$ & $(0.00789)$ & $(0.00744)$ & $(0.0211)$ \\
& $-0.0447^{* * *}$ & $-0.0384 * * *$ & $-0.109 * * *$ \\
\hline Observations & $(0.00931)$ & $(0.00878)$ & $(0.0252)$ \\
\hline
\end{tabular}




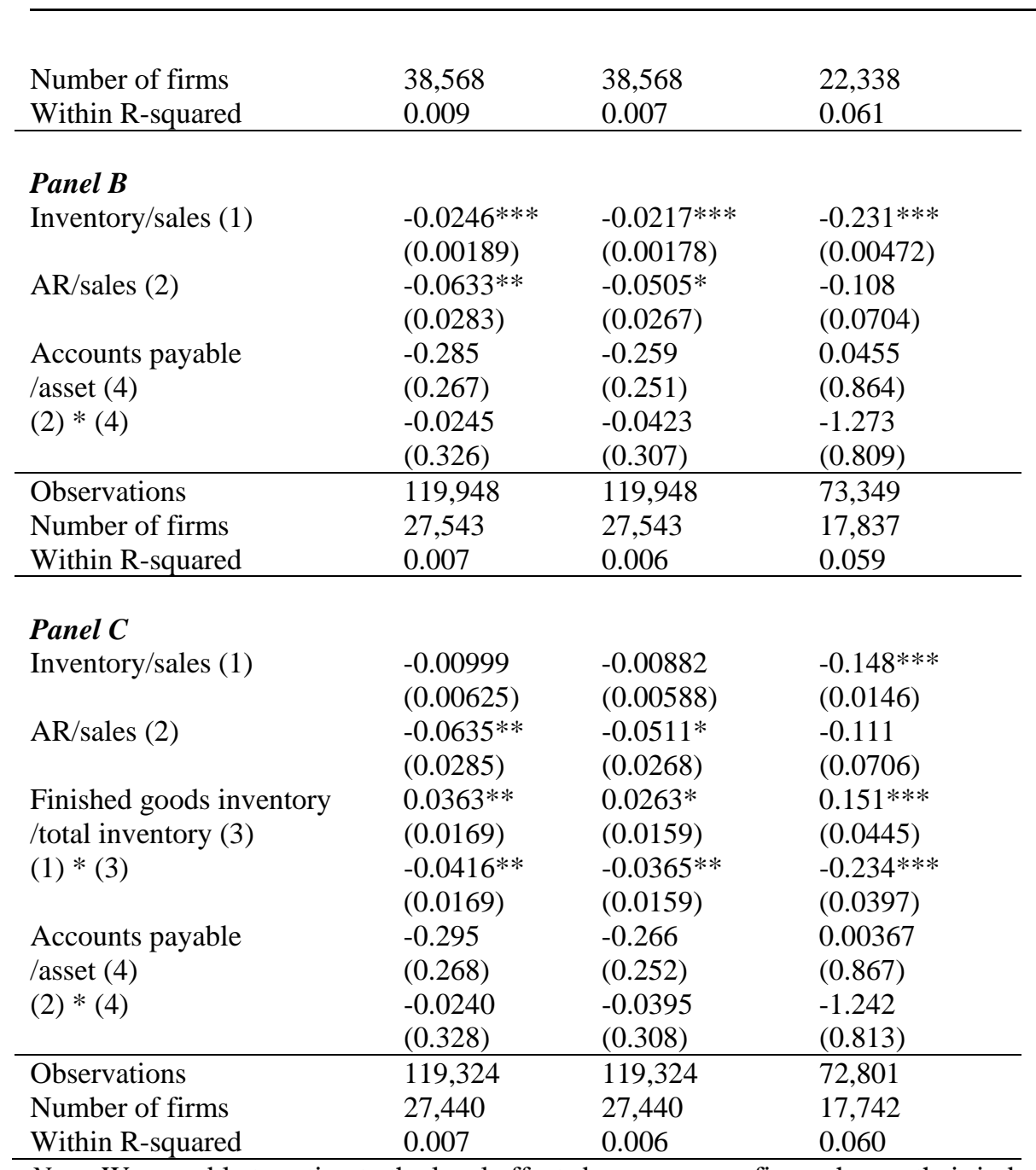

Note: We are able to estimate the level effects because some firms change their industries over time. 